УДК 321:323

DOI https://doi.org/10.32849/2663-5313/2020.5.35

Михайло Кельман,

докт. юрид. наук,

професор кафедри теорії, історії та філософії права

Національного університету «Львівська політехніка»

Мирослава Кристиняк,

стариий лаборант кафедри адміністративного та інформаційного права

Національного університету «Львівська політехніка»

\title{
ПРОБЛЕМИ РОЗВИТКУ ТА ЯКІСНОГО ФОРМУВАННЯ УКРАЇНСЬКОЇ ЕЛІТИ
}

У статті на основі вивчення та аналізу відповідних літературних джерел визначено наукові погляди щодо проблем формування та розвитку української еліти, зокрема управлінської як однієї із ключових еліт, що бере участь у розбудові держави та формує стандарти і закони розвитку суспільства загалом. 3'ясовано, що наявність численних проблем розвитку зумовлює порушення важливих функиій влади, яка десятирічиями сприяє формуванню патронажно-клієнтських стосунків та укріпленню приватної власності за рахунок збереження персоніфікації владних інтересів. Така ситуачія загалом зумовлює постійне «виживання» суспільства в очікуванні нових криз та змушує активну частину пращездатних осіб полишати державу з метою виживання та збереження нормального рівня життя. Окрім иього, прийняті неформальні стандарти прорадянського прочесу правління державою аж ніяк не сприяють ї̈ ефективній розбудові, що і призводить до численних кризових явищ та ще більще поглиблює занепад важливих макроекономічних показників розвитку держави загалом. Отже, для ефективної розбудови держави потрібно змінювати політичну культуру, проте, щоб ї змінити, потрібно знати, які проблеми є $i$ як їх правильно вирішити, не поглибивщи ще більше. Тому, на наш погляд, натепер назріла гостра необхідність зробити перші зміни через запуск прочесу зміни лідерів та формування механізму відбору, в якому пріоритет будуть мати засадничі моральні иінності та демократичні пріоритети, що допоможе підвищити соціально-політичну відповідальність та свідомість влади. Формування механізму відбору повинно грунтуватися на відповідному формуванні високої компетентності управліниів, фахової підготовки та активності населення у формуванні інститутів влади. Це допоможе сформувати потрібну політику та осіб, які будуть ї правильно провадити, враховуючи основні інтереси суспільства, дбаючи про формування національної свідомості та соціальної відповідальності підлеглих, що загалом допоможе розбудувати державу та змічнити ї конкурентні позииї.

Ключові слова: еліта, управління, розбудова держави, політична культура, національна свідомість.

Постановка проблеми. Перебіг сучасних політичних процесів у країні змушують по-новому підійти до розгляду такого феномена, як еліта, адже саме за їі допомогою в державі здійснюються важливі соціальноекономічні процеси правління, які відбиваються на житті усього суспільства та за загалом формують відповідний рівень життя населення кожної держави загалом. Таким чином, будь-який відповідний економічний та соціальний розвиток держави та суспільства у ній залежить від якості процесу правління влади, а саме прийняття нею обгрунтованих управлінських рішень для покращення якості життя населення. 3 огляду на численні соціально-економічні проблеми розвитку України, постає питання про проблеми розвитку еліти в Україні, що й зумовило актуальність даного дослідження.
Аналіз останніх досліджень і публікацій. Значний науковий внесок у дослідження проблем формування та розвитку еліти в державі зробили відомі науковці, серед яких Г. Ашин, В. Добіжа, С. Телешун, В. Фесенко, О. Крюков та інші, праці яких досліджено в даній статті та на основі цього визначені основні шляхи покращення її формування.

Мета статті - дослідити ключові проблеми розвитку української еліти та на основі цього запропонувати основні шляхи покращення іï формування.

Виклад основного матеріалу. Як зазначалося, наявність значної кількості проблем розвитку, серед яких, на наш погляд, ключовими стали неналежні управлінські процеси стосовно ведення військово-політичних дій 
в Україні на сході держави, тривалість яких виснажила економіку до критичних меж, що зумовлюе низькі макроекономічні показ ники розвитку, високі банківські кредити, особливо для малого та середнього бізнесу, відсутність програм фінансування малого підприємництва та збільшення рівня безробіття в державі. Перелік проблем можна кількісно розширити, проте наявність вже перелічених проблем дає підставу говорити про неякісний процес управління i, як наслідок, проблему якісного формування влади в Україні.

Так, Г. Ашин стверджує, що натепер еліта у нашому суспільстві, не маючи науково обгрунтованої парадигми розвитку держави, достатньої управлінської компетентності, лідерських та моральних якостей, користується перевагами привілейованого становища [1].

С. Телешун має схожий погляд, а саме, він зазначає, що українським елітам притаманна діяльність на основі ведення «візантійської політики», де ключовий вплив проявляється не за рахунок матеріальних ресурсів та інтелекту, а за рахунок «закулісної гри», особистих відносин, що обмежують доступ до політичних ресурсів більш широким соціальним групам [3].

Стосовно цього В. Добіжа зазначає, що влада весь час вирішує питання на свою користь, відступаючи від державницьких, національних цінностей, залишаючи народ позаду в перегонах за титулами і чинами [2]. Таким чином, брак національної еліти - це головна небезпека для історичних перспектив незалежної України [4, с. 117].

Як зазначає О. Крюков, успадкувавши від радянських часів генотип ідеократичного традиційного суспільства, українське суспільство всіляко хоче його зберегти, і в цих умовах стало явним неприйняття більшістю громадян України на перших стадіях трансформації системи соціал-дарвіністичних методів управління суспільством [5].

3 огляду на вище проаналізовані наукові погляди на проблеми розвитку та діяльності управлінської еліти як ключової складової частини української еліти, доречно, на наш погляд, визначити основні проблеми розвитку, серед яких варто відзначити:

- наявність соціал-дарвіністичних методів управління державою управлінською елітою, яка вийшла з Радянського союзу і до сих пір має уставлені прорадянські погляди щодо процесу правління державою;

- вирішення загально-державних питань на свою користь; відступаючи від державницьких, національних цінностей, залишаючи народ позаду в перегонах за титулами і чинами, як правильно було зазначено вище, нехтуючи цінностями, влада задовольняє власні інтереси, ігноруючи основні потреби населення;

- українським елітам, як вище було слушно зазначено, притаманна діяльність на основі ведення «візантійської політики», де ключовий вплив проявляється не за рахунок наявності значних матеріальних ресурсів;

- представники української еліти не мають достатньої управлінської компетентності, лідерських та моральних якостей, притому користуються перевагами привілейованого становища.

Таким чином, аналіз наведених наукових поглядів дозволив визначити основні проблеми як розвитку, так і формування управлінської еліти як однієї 3 ключових еліт. Прийняті неформальні стандарти правління не сприяють ефективній розбудові держави, що призводить до численних кризових явищ та поглиблює занепад макроекономічних показників розвитку держави. Тому для ефективної розбудови держави потрібно насамперед запровадити такі зміни: сформувати якісну політичну культуру (на наш погляд, це необхідно зробити перш за все шляхом зміни лідерів, формування механізму відбору, в якому пріоритет будуть мати засадничі моральні цінності, що допоможе підвищити соціально-поличну відповідальність та свідомість влади), встановити відповідний правовий механізм, який би гарантував дотримання встановлених норм та законів.

\section{Висновки}

Проведене дослідження дає підставу говорити про необхідність вжиття заходів щодо формування відповідного управлінського апарату, котрий потребує оновлення через неналежне здійснення управлінського процесу, який не дозволяє розбудувати державу та утримати іiі конкурентні позиції на світовому ринку. Аналіз викладених авторських поглядів дає підставу дійти висновку, що наявні проблеми пов'язані насамперед із прорадянськими стереотипами правління, які спрямовані не на розбудову окремої держави, а на їі повернення до колишнього авторитарного режиму правління. Зазначені думки потребують проведення глибшого теоретичного дослідження з метою ширшого висвітлення нових проблем формування еліти.

\section{Список використаних джерел:}

1. Ашин Г. К., Охотский Е. В.. Курс элитологии. Москва : ЗАО «Спортакадемпресс», 1999. 91 с. 
2. Добіжа В.В. Політична культура владної еліти в умовах суспільно-політичної трансформації. Держава $i$ право. Юридичні $i$ політичні науки. Київ : Ін-т держави і права НАНУ, 2007. Вип. 38. С. 726-732.

3.Телешун С., Колпаков А. Политическая элита в Украине. Новая система власти. URL: http://rus.for-ua.com/analit/2002/07/18/ 132522 html (дата звернення: 05.01.2020).

4. Фесенко В. Формування нової української еліти. Ї. 2006 № 45. С. 117-121.

5. Крюков О. І. Політико-управлінська еліта України як чинник державотворення : монографія / за наук. ред. Е. А. Афоніна. Київ : Вид-во НАДУ, 2006. 252 с.

In the article, based on the study and analysis of relevant literary sources, the author identifies scientific views on the problems of formation and development of the Ukrainian elite, in particular, the administrative elite, which is one of the key elites participating in the development of the state and generally defines the standards and lawes of the development of society as a whole. Therefore, the presence of numerous problems of development implies the existence of violations of important functions of the government, which for decades promoted the formation of patronage-client relations and the strengthening of private property at the expense of preserving the personification of power interests. This situation generally contributes to the constant "survival" of society in the face of new crises and causes an active part of able-bodied individuals to leave the state in order to survive and maintain a normal standard of living. In addition, the adopted informal standards of the pro-Soviet process of government do not contribute to its effective development, which in general leads to numerous crisis phenomena and further aggravates the decline of important macroeconomic indicators of the development of the state as a whole. Therefore, to develop the state effectively, it is necessary to change the political culture, but in order to change it, one must know what problems are present and how to solve them properly without further aggravating them. , at the same time, creating a selection mechanism that will prioritize fundamental moral values and democratic priorities, which will help to increase the socio-political responsibility and consciousness of the authorities. Therefore, the formation of the selection mechanism should be based on the appropriate formation of high competence of managers, professional training and activity of the population in the formation of government institutions. This will help to shape the right policy and the people who will implement it correctly, taking into account the basic interests of society, taking care of the formation of national consciousness and social responsibility of subordinates, which in general will help to build the state and strengthen its competitive position.

Key words: elite, management, state building, political culture, national consciousness. 